\title{
Role of medial prefrontal cortex Narp in the extinction of morphine conditioned place preference
}

\author{
Ashley M. Blouin, ${ }^{1,6}$ Sungho Han, ${ }^{1}$ Anne M. Pearce, ${ }^{2}$ KaiLun Cheng, ${ }^{1}$ JongAh J. Lee, ${ }^{1}$ \\ Alexander W. Johnson, ${ }^{2}$ Chuansong Wang, ${ }^{3}$ Matthew J. During, ${ }^{3}$ Peter C. Holland, ${ }^{2,4}$ \\ Yavin Shaham, ${ }^{5}$ Jay M. Baraban, ${ }^{1,4}$ and Irving M. Reti ${ }^{1,4}$ \\ ${ }^{1}$ Department of Psychiatry and Behavioral Sciences, Johns Hopkins School of Medicine, Baltimore, Maryland, 21205, USA; \\ ${ }^{2}$ Department of Psychological and Brain Sciences, Johns Hopkins University, Baltimore, Maryland, 21218, USA; ${ }^{3}$ Department of \\ Molecular Virology, Immunology and Molecular Genetics, Ohio State University, Columbus, Ohio, 43210, USA; ${ }^{4}$ Solomon Snyder \\ Department of Neuroscience, Johns Hopkins School of Medicine, Baltimore, Maryland, 21205, USA; ${ }^{5}$ The National Institutes of \\ Health, National Institute on Drug Abuse, Intramural Research Program (NIH/NIDA/IRP), Baltimore, Maryland, 21224, USA
}

\begin{abstract}
Narp knockout (KO) mice demonstrate an impaired extinction of morphine conditioned place preference (CPP). Because the medial prefrontal cortex (mPFC) has been implicated in extinction learning, we tested whether Narp cells in this region play a role in the extinction of morphine CPP. We found that intracranial injections of adenoassociated virus (AAV) expressing wild-type (WT) Narp into the mPFC of Narp KO mice rescued the extinction and the injection of AAV expressing a dominant negative form of Narp (NarpN) into the mPFC of WT mice impaired the extinction of morphine CPP. These findings suggest that Narp in the mPFC mediates the extinction of morphine CPP.
\end{abstract}

[Supplemental material is available for this article.]

Neuronal activity-regulated pentraxin (Narp) is an immediate early gene product that is induced by neuronal activity and is secreted at synapses where it binds to the extracellular surface of AMPA receptors (AMPARs; O'Brien et al. 1999). Narp-positive neurons are present in many limbic and cortical regions, including the medial prefrontal cortex (mPFC), hippocampus, hypothalamus, and amygdala (Tsui et al. 1996; Reti et al. 2002a,b; Reti and Baraban 2003; Johnson et al. 2010). Narp has been implicated in regulating AMPAR trafficking (O'Brien et al. 1999, 2002), a cellular event that plays a role in synaptic plasticity (Anggono and Huganir 2012), and cue- and context-induced drug seeking (Van den Oever et al. 2010; Wolf and Ferrario 2010; Dias et al. 2012).

Several studies have implicated Narp in mediating responses to drugs of abuse. Recent evidence indicates that Narp expression in the nucleus accumbens is increased by alcohol consumption (Ary et al. 2012). Narp expression is also increased by withdrawal from opiates, nicotine, and $\Delta(9)$-tetrahydrocannabinol (Reti and Baraban 2003; Reti et al. 2009), and mice lacking Narp have altered responses to cocaine (Pacchioni and Kalivas 2009; Pacchioni et al. 2009) and alcohol (Ary et al. 2012). Other studies show that cocaine does not alter Narp expression, but that Narp is involved in responding to a novel environment (Lu et al. 2002).

In previous studies we found that Narp knockout (KO) mice acquire instrumental and Pavlovian learning normally (Johnson et al. 2007; Crombag et al. 2009). In contrast, Narp KO mice show behavioral inflexibility after learning has occurred. Specifically, Narp KO mice are deficient in a food devaluation procedure (Johnson et al. 2007) and have impaired extinction of morphine conditioned place preference (CPP, Crombag et al. 2009).

Extinction deficits are thought to play a key role in drug addiction and anxiety disorders (Peters et al. 2009). Previous studies

\section{${ }^{6}$ Corresponding author}

E-mail ablouin1@jhmi.edu

Article is online at http://www.learnmem.org/cgi/doi/10.1101/Im.028621.112. have focused attention on the role of the infralimbic region (IL) of the $\mathrm{mPFC}$ in the extinction of aversive and appetitive learning (Peters et al. 2009; LaLumiere et al. 2010; Myers and Carlezon 2010; Millan et al. 2011). The IL is one of the cortical regions with a prominent population of Narp-positive neurons; therefore, we tested the hypothesis that Narp expressed in these neurons plays a role in mediating the extinction of morphine CPP. An additional rationale for selecting this region was provided by our previous studies demonstrating that selective expression of a Narp-dominant negative construct in $\mathrm{mPFC}$ mimicked the deficit in food reward devaluation observed in the global Narp KO (Johnson et al. 2010).

In this report, we have assessed whether local adenoassociated virus (AAV)-mediated expression of wild-type Narp (WTN) in the IL mPFC of Narp KO mice would be sufficient to rescue the extinction of morphine CPP. Conversely, we have also determined whether localized expression of a Narp-dominant negative construct (AAV-NarpN) in the IL mPFC is sufficient to block the extinction of morphine CPP in wild-type (WT) mice.

Morphine CPP was conducted using 10-week-old male Narp KO and WT mice (Johnson et al. 2007) obtained by breeding Narp heterozygotes that had been backcrossed 12 times to the C57BL/6 strain. Mice were kept on a 12-h-light/dark cycle (lights on 07:0019:00), and CPP training, testing, and extinction occurred during the hours of 09:00-15:00. Food and water were freely available in the home cage.

Mice were anesthetized with ketamine/xylazine (80 and $12 \mathrm{mg} / \mathrm{kg}$, respectively, i.p.) and 26-gauge bilateral cannulae were implanted above the IL mPFC $(\mathrm{AP}+2.2, \mathrm{ML} \pm 0.4, \mathrm{DV}-1.8$, Plastics One) and secured to the skull with dental cement. The 33-gauge internal cannulae extended $1.2 \mathrm{~mm}$ beyond the guide cannulae. Four weeks following cannulae implantation, place conditioning began (see Crombag et al. 2009 and Supplemental Material for details). During the pre-conditioning (bias) test, mice were placed in the chambers with half grid and half hole 
floors for $30 \mathrm{~min}$. Following the pre-conditioning test, on alternate days, mice received an injection of saline paired with a $30-\mathrm{min}$ placement on one floor type or of morphine $(10 \mathrm{mg} / \mathrm{kg}$, dissolved in saline, i.p.) paired with 30-min placement on the alternate floor type, for a total of eight conditioning sessions; injections were given immediately prior to placement. On the next day, the mice were tested for morphine CPP (30-min test), using procedures identical to those of the pre-conditioning test. Two days later, mice were anesthetized as described above and $1 \mu \mathrm{L}$ of virus (see Supplemental Material for details) was injected through the bilateral cannulae into the IL mPFC $(\mathrm{AP}+2.2$, L \pm 0.4, V -3.0 ; Paxinos and Franklin 2004). AAV-WTN or AAV-YFP was injected into Narp KO mice $(n=12$ per group), and AAV-NarpN or AAV-YFP was injected into WT mice $(n=12$ and 11 , respectively). The mice remained in their home cage for 2 wk to allow for adequate viral expression.

Following this period, the mice underwent 10 repeated extinction sessions (30 min, twice daily) identical to the preconditioning and post-conditioning tests. A timeline of the placepreference procedure is presented in Figure 1A. Preference score was the dependent measure for the CPP pre-conditioning test, post-conditioning test, and extinction. The preference score was calculated by subtracting the time (sec) on the saline-paired side from the time (sec) on the morphine-paired side. ANCOVAs using the post-conditioning test preference score as a co-variate followed by Fisher's LSD post-hoc tests were used to analyze extinction data. Statistical significance was determined by $P<0.05$.

Following extinction, $\mathrm{mPFC}$ sections were processed and YFP fluorescence was visualized directly. Immunostaining was performed according to Reti et al. (2002a) and Johnson et al. (2010; also described in the Supplemental Material). The percentage of the IL region expressing AAV-WTN, AAV-NarpN, or AAV-YFP was then quantified (see Johnson et al. 2010 and Supplemental Material for details). To assess the spread of the virus, the percentage of the prelimbic (PrL) region expressing viral product was also quantified.

Prior to evaluating the effect of IL injections on the extinction of morphine CPP, we determined that all groups acquired drug CPP. Overall, the performance and variability of the Narp $\mathrm{KO}$ and WT mice in the CPP paradigm were similar to those observed previously (Crombag et al. 2009). Consistent with our previous study, the KO (Fig. 1B) and WT (Fig. 1C) mice acquired morphine CPP and did not differ in their preference scores. The preference score data were analyzed with mixed ANOVA using the between-subjects factors of Genotype (KO, WT) and the within-subjects factors of Session (pre-conditioning, post-conditioning). This analysis demonstrated a main effect of Session $\left(F_{(1,45)}=26.1, P<0.01\right)$, but not of Genotype or an interaction between the two factors $(P>0.1)$.

Following the post-conditioning test, the KO group was subdivided into two groups, one that received injections of a control virus (AAV-YFP) and one that received injections of AAV-WTN. The WT group was also subdivided into two groups, one that received injections of AAV-YFP and one that received injections of AAV-NarpN. All groups were matched for their post-conditioning preference scores (Fig. 1B,C). To assess whether local expression of Narp in the IL mPFC can rescue the deficit in the extinction of morphine CPP observed in the global Narp KO mice, we compared the performance of Narp KO mice receiving IL injections of AAV-YFP with that of Narp KO mice receiving IL injections of AAV-WTN over the course of multiple extinction sessions (Fig. 2A). A Virus Condition (YFP or WTN) by Session (extinction session
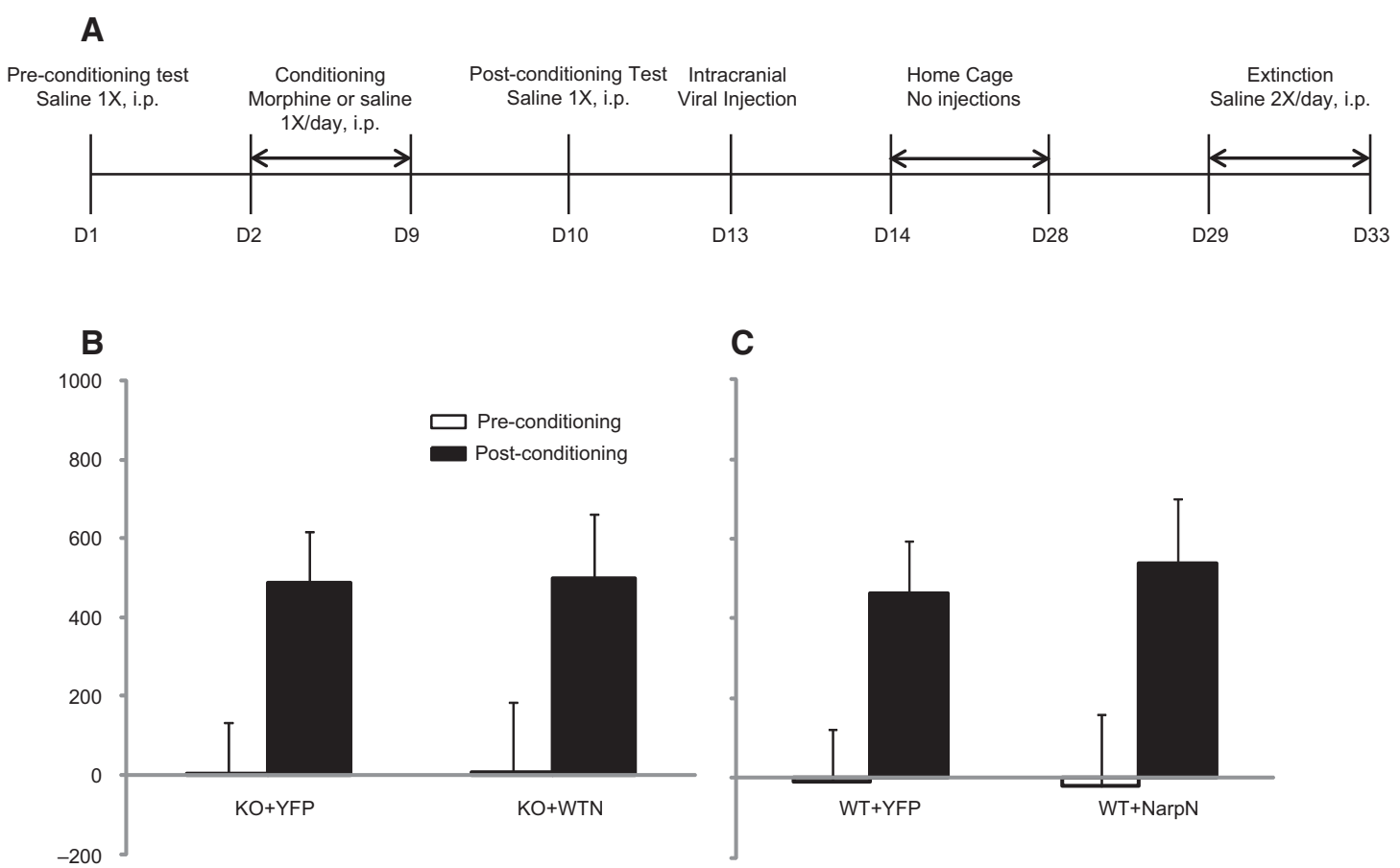

Figure 1. (A) Timeline of the CPP procedure shows the stage of the procedure and the schedule of injections. (B) Preference scores before and after conditioning of KO mice receiving YFP after the post-conditioning test (KO + YFP) and KO mice receiving WTN after the post-conditioning test (KO + WTN). (C) WT mice receiving YFP after the post-conditioning test (WT + YFP) and WT mice receiving NarpN after the post-conditioning test (WT + NarpN). All groups were matched based on post-conditioning preference scores. White bars indicate preference scores prior to conditioning and black bars indicate preference scores after conditioning. All groups of mice acquired the CPP task. No significant differences were found between KO or WT mice in the acquisition. Error bars represent \pm SEM, $n=11-12$ per group. (KO) knockout, (WT) wild-type, (YFP) yellow fluorescent protein, (WTN) wild-type Narp, (NarpN) dominant negative Narp. 
1 through 10) ANCOVA showed a significant Virus Condition $\times$ Session interaction $\left(F_{(9,189)}=4.18, P<0.01\right)$. Furthermore, injection of AAV-NarpN into the IL mPFC of WT mice blocked the extinction of CPP under conditions that produced extinction in YFP-injected WT mice (Fig. 2B). In the WT mice, a Virus Condition (YFP or NarpN) by Session ANCOVA showed a significant effect of Virus Condition $\left(F_{(1,20)}=5.01, P=0.04\right)$.

Injection of AAV-NarpN, AAV-YFP, and AAV-WTN viruses resulted in $>60 \%$ infection of the IL mPFC in mice and $\sim 40 \%$ infection of the PrL (Fig. 3). A one-way ANOVA showed no differences in IL mPFC viral expression among the groups. In all groups, paired $t$-tests showed that IL mPFC viral expression was significantly greater than viral expression which spread to the PrL (Fig. 3E,F; WT + YFP: $P=0002, t=5.79 ; \mathrm{WT}+\mathrm{NarpN}: P=0.02, t=$ 2.83; KO + YFP: $P=0.0003, t=5.31 ; \mathrm{KO}+\mathrm{WTN}: P<0.0001$, $t=6.78)$.

Using a viral-based expression of wild-type Narp or a dominant negative Narp construct, we have examined the role of Narp-expressing neurons in the mPFC in the extinction of morphine CPP. We found that selective expression of Narp in the mPFC reversed the impaired extinction displayed by Narp KO mice. Conversely, selective expression of the NarpN construct in the mPFC of WT mice mimicked the deficit in extinction observed in Narp KO mice in the morphine CPP procedure. Although the expression of mPFC NarpN resulted in a complete blockade of extinction in the WT mouse, this blockade was evident from the first day of extinction. Because the post-conditioning test is identical to an extinction session, the WT controls may have retained some extinction memory over the 2-wk interval between the postconditioning test and the first extinction session. Injection of NarpN into the mPFC following the post-conditioning test may have blocked the retention or expression of this extinction memory.

Local injections of viral vectors allowed us to manipulate Narp expression with both anatomical and temporal control. Therefore, compared to prior studies conducted with global Narp KO mice, these studies enabled us to define with much greater precision where and when Narp expression is critical for the extinction of morphine CPP. The ability of a local injection of NarpN to block extinction in WT mice indicates that Narp expression in
mPFC neurons is necessary for extinction to occur. Furthermore, since NarpN was injected into mice following the acquisition of morphine CPP, we can infer that Narp is needed in mPFC neurons during the extinction phase. Furthermore, mPFC injection of AAV-WTN following acquisition rescued the extinction of morphine CPP in Narp KO mice, indicating that Narp expression is not needed during acquisition in order for normal extinction to occur. Taken together, the results of these viral injection studies indicate that even though Narp is expressed in multiple brain areas, its expression in the mPFC during extinction is both necessary and sufficient for the extinction of morphine CPP to occur.

Although viral injections were aimed at the IL region, the virus spread to the PrL region. Thus, Narp cells in either or both of these $\mathrm{mPFC}$ regions may play a role in the extinction of morphine CPP. However, viral expression in the IL was significantly greater than that in the PrL region. In addition, cells of the IL region are known to play a critical role in the extinction of both appetitive and aversive learning (Santini et al. 2008; Laurent and Westbrook 2009; Peters et al. 2009; Kim et al. 2010; LaLumiere et al. 2010; Millan et al. 2011). Although little is known about the specific signaling pathways in the IL that mediate the extinction of morphine CPP, a recent study indicates that inhibiting $\mathrm{PKM} \zeta$ in the IL but not in the PrL region of the mPFC blocks the extinction of morphine CPP (He et al. 2011). PKM $\zeta$, like Narp, has been shown to regulate AMPARs and is thought to act postsynaptically (Yao et al. 2008). Thus, PKM $\zeta$ likely regulates AMPARs on IL neurons, while Narp is secreted from these neurons and may bind to AMPARs in the IL or in other brain regions. It may be interesting to determine whether PKM $\zeta^{\prime}$ 's effect on extinction is mediated by its actions in Narp neurons located in the IL mPFC.

Narp is expressed in glutamatergic neurons and is trafficked from the cell body to axon terminals, where it is thought to act on AMPARs located on target neurons (O'Brien et al. 2002). Thus, while the results presented in our study demonstrate that Narp neurons located in the mPFC play a key role in the extinction of morphine CPP, Narp may exert its effect on AMPAR trafficking in target neurons located in downstream regions that are proposed to mediate extinction learning (Schroeder and Packard 2003; Peters et al. 2009; Myers and Carlezon 2010). Previous studies indicate that projections from the mPFC to the amygdala (Quirk et al. 2003; Peters et al. 2009; Myers and Carlezon 2010; Van den Oever et al. 2010) and to the nucleus accumbens shell (Peters et al. 2008, 2009; Muschamp et al. 2010) play a role in the extinction of both appetitive and aversive responding. Furthermore, studies show that extinction training decreases the cell-surface expression of the GluR1 subunit of the AMPAR in the basolateral amygdala (Kim et al. 2007; Myers et al. 2011) and increases GluR1 expression in the accumbens shell (Sutton et al. 2003; Ghasemzadeh et al. 2009; Wolf and Ferrario 2010). Although increases in GluR1 expression in the accumbens shell have been shown to accompany extinction learning, similar increases have been associated with increased drug and alcohol consumption (Conrad et al. 2008; Ping et al. 2008; Reissner et al. 2011; Ary et al. 2012; Shabashov et al. 2012). Therefore, the exact role of accumbens GluR1 expression changes in addiction behavior is unclear. Since retrograde tracing studies indicate 


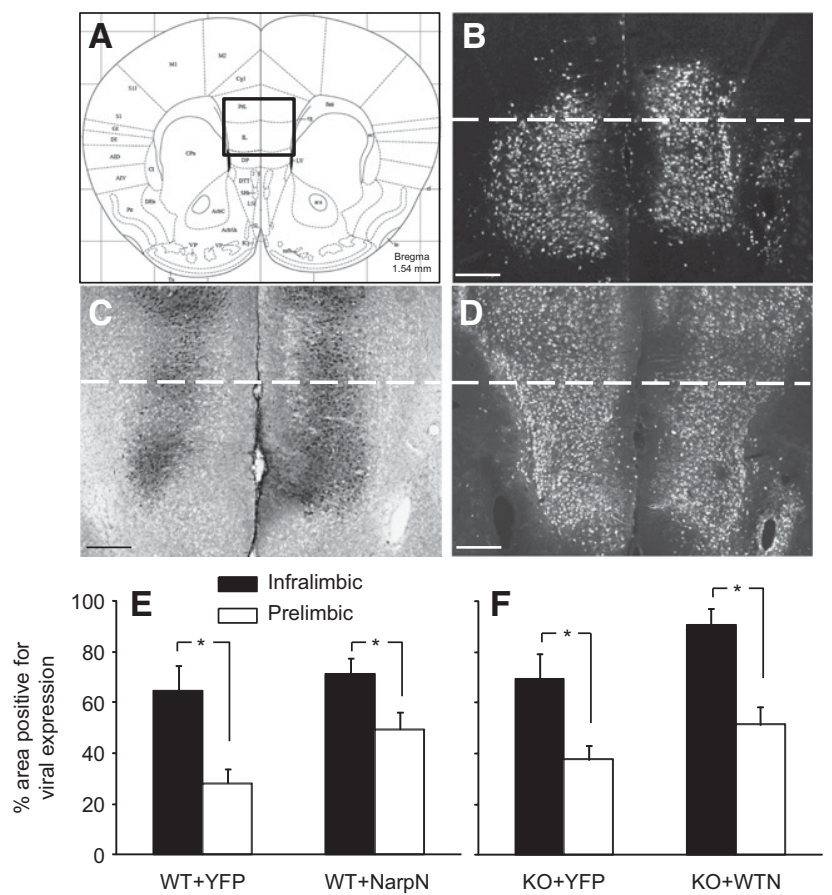

Figure 3. Viral injection into the IL mPFC of mice. $(A)$ Location of viral injections shown in $B-D$. (B) AAV-YFP visualized directly. (C) AAV-NarpN visualized by myc immunostaining with $D A B$ (the NarpN construct contains a C-terminal myc tag). (D) AAV-WTN visualized by Narp immunostaining with tyramide. ( $E, F)$ Quantification of viral expression in the IL (black bars) and spread to PrL (white bars) in WT mice $(E)$ and KO mice $(F)$. Viral expression was quantified by visualizing YFP directly or by monitoring Narp or myc immunostaining. Although virus spread to the PrL region at this level (Bregma $1.54 \mathrm{~mm}$ ), more anterior sections (Bregma $2.1-3.08 \mathrm{~mm}$ ) had $<10 \%$ of the viral product in the PrL region. Expression was significantly greater in the IL region than in the PrL region and IL viral expression did not differ among the groups. Error bars, \pm SEM, $n=11-12$ per group; dashed lines, the division between the PrL and IL regions; scale bar, $0.25 \mathrm{~mm}$. (*) $P<0.05$, (KO) knockout, (WT) wild type, (YFP) yellow fluorescent protein, (WTN) wild-type Narp, (NarpN) dominant negative Narp (DAB) diaminobenzidine.

that Narp cells of the mPFC project to both the nucleus accumbens and to the amygdala (Johnson et al. 2010; data not shown), Narp secreted from the mPFC may participate in the trafficking of AMPARs that occur in these downstream regions during the extinction of drug seeking.

In addition to the possibility that Narp neurons modulate AMPARs in downstream regions, it is also possible that mPFC Narp neurons send collaterals locally to neurons in the mPFC. If this is the case, it is unknown whether mPFC Narp neurons send local projections to glutamatergic cells or to GABAergic interneurons. Some evidence indicates that Narp can cluster AMPARs on GABAergic interneurons, facilitating network inhibition in the hippocampus (Chang et al. 2010). Thus, it is possible that Narp could cluster AMPARs on GABAergic interneurons in the PrL region and inhibit PrL cells which are thought to promote conditioned responding (Peters et al. 2009). Our retrograde studies indicate that Narp cells in the IL send projections to the PrL mPFC (data not shown). Narp may also cluster AMPARs on GABAergic cells in downstream regions, such as on BLA interneurons or on the GABAergic intercalated cells of the amygdala, which inhibit output of the central nucleus of the amygdala and conditioned responding (Quirk et al. 2003; Myers et al. 2011). Further studies aimed at determining which mPFC Narp cells mediate the extinction of morphine CPP and identifying their targets may be useful in defining the circuitry underlying extinction learning.

In summary, using viral-mediated knockdown and rescue of Narp in cells of the mPFC of mice that have already acquired morphine CPP, our results indicate that Narp in the MPFC is required for the extinction of morphine CPP to occur. In light of these findings, it will be interesting, in future studies, to determine whether Narp cells in the mPFC are also involved in other types of extinction learning, such as fear extinction, extinction of CPP to other drugs of abuse, or extinction of drug selfadministration.

\section{Acknowledgments}

We thank Zhi Li and Edward Retzbach for technical assistance. The Narp antibody was provided by Dr. Paul Worley (Solomon Snyder Department of Neuroscience, Johns Hopkins School of Medicine, Baltimore, MD). This work was funded by RO1 DA016303 and NIDA 5R25DA21630-3. The write-up of this manuscript was also supported in part by funds to the intramural research program of NIDA.

\section{References}

Anggono V, Huganir RL. 2012. Regulation of AMPA receptor trafficking and synaptic plasticity. Curr Opin Neurobiol 22: 461-469.

Ary AW, Cozzoli DK, Finn DA, Crabbe JC, Dehoff MH, Worley PF, Szumlinski KK. 2012. Ethanol up-regulates nucleus accumbens neuronal activity dependent pentraxin (Narp): Implications for alcohol-induced behavioral plasticity. Alcohol 46: 377-387.

Chang MC, Park JM, Pelkey KA, Grabenstatter HL, Xu D, Linden DJ, Sutula TP, McBain CJ, Worley PF. 2010. Narp regulates homeostatic scaling of excitatory synapses on parvalbumin-expressing interneurons. Nat Neurosci 13: 1090-1097.

Conrad KL, Tseng KY, Uejima JL, Reimers JM, Heng LJ, Shaham Y, Marinelli M, Wolf ME. 2008. Formation of accumbens GluR2-lacking AMPA receptors mediates incubation of cocaine craving. Nature 454: $118-121$.

Crombag HS, Dickson M, Dinenna M, Johnson AW, Perin MS, Holland PC, Baraban JM, Reti IM. 2009. Narp deletion blocks extinction of morphine place preference conditioning. Neuropsychopharmacology 34: $857-866$.

Dias C, Wang YT, Phillips AG. 2012. Facilitated extinction of morphine conditioned place preference with Tat-GluA2(3Y) interference peptide. Behav Brain Res 233: 389-397.

Ghasemzadeh MB, Vasudevan P, Mueller C, Seubert C, Mantsch JR. 2009. Region specific alterations in glutamate receptor expression and subcellular distribution following extinction of cocaine self-administration. Brain Res 1267: 89-102.

He YY, Xue YX, Wang JS, Fang Q, Liu JF, Xue LF, Lu L. 2011. PKM ל maintains drug reward and aversion memory in the basolateral amygdala and extinction memory in the infralimbic cortex. Neuropsychopharmacology 36: $1972-1981$.

Johnson AW, Crombag HS, Takamiya K, Baraban JM, Holland PC, Huganir RL, Reti IM. 2007. A selective role for neuronal activity regulated pentraxin in the processing of sensory-specific incentive value. J Neurosci 27: 13430-13435.

Johnson AW, Han S, Blouin AM, Saini J, Worley PF, During MJ, Holland PC, Baraban JM, Reti IM. 2010. Localized disruption of Narp in medial prefrontal cortex blocks reinforcer devaluation performance. Learn Mem 17: 620-626.

Kim J, Lee S, Park K, Hong I, Song B, Son G, Park H, Kim WR, Park E, Choe HK, et al. 2007. Amygdala depotentiation and fear extinction. Proc Natl Acad Sci 104: 20955-20960.

Kim SC, Jo YS, Kim IH, Kim H, Choi JS. 2010. Lack of medial prefrontal cortex activation underlies the immediate extinction deficit. J Neurosci 30: $832-837$.

LaLumiere RT, Niehoff KE, Kalivas PW. 2010. The infralimbic cortex regulates the consolidation of extinction after cocaine self-administration. Learn Mem 17: 168-175.

Laurent V, Westbrook RF. 2009. Inactivation of the infralimbic but not the prelimbic cortex impairs consolidation and retrieval of fear extinction. Learn Mem 16: 520-529.

Lu W, Marinelli M, Xu D, Worley PF, Wolf ME. 2002. Amphetamine and cocaine do not increase Narp expression in rat ventral tegmental area nucleus accumbens or prefrontal cortex, but Narp may contribute to 
individual differences in responding to a novel environment. Eur $J$ Neurosci 15: 2027-2036.

Millan EZ, Marchant NJ, McNally GP. 2011. Extinction of drug seeking. Behav Brain Res 217: 454-462.

Muschamp JW, Van't Veer A, Parsegian A, Gallo MS, Chen M, Neve RL, Meloni EG, Carlezon WA Jr. 2010. Activation of CREB in the nucleus accumbens shell produces anhedonia and resistance to extinction of fear in rats. J Neurosci 31: 3095-3103.

Myers KM, Carlezon WA Jr. 2010. Extinction of drug- and withdrawal-paired cues in animal models: Relevance to the treatment of addiction. Neurosci Biobehav Rev 35: 285-302.

Myers KM, Carlezon WA Jr, Davis M. 2011. Glutamate receptors in extinction and extinction-based therapies for psychiatric illness. Neuropsychopharmacology 36: 274-293.

O’Brien RJ, Xu D, Petralia RS, Steward O, Huganir RL, Worley P. 1999. Synaptic clustering of AMPA receptors by the extracellular immediate-early gene product Narp. Neuron 23: 309-323.

O'Brien R, Xu D, Mi R, Tang X, Hopf C, Worley P. 2002. Synaptically targeted Narp plays an essential role in the aggregation of AMPA receptors at excitatory synapses in cultured spinal neurons. J Neurosci 22: $4487-4498$

Pacchioni AM, Kalivas PW. 2009. The role of AMPAR trafficking mediated by neuronal pentraxins in cocaine-induced neuroadaptations. Mol Cell Pharmacol 1: 183-192.

Pacchioni AM, Vallone J, Worley PF, Kalivas PW. 2009. Neuronal pentraxins modulate cocaine-induced neuroadaptations. J Pharmacol Exp Ther 328: $183-192$.

Paxinos G, Franklin KBJ. 2004. The mouse brain in stereotaxic coordinates, 2nd ed. Elsevier Academic Press, San Diego, CA.

Peters J, LaLumiere RT, Kalivas PW. 2008. Infralimbic prefrontal cortex is responsible for inhibiting cocaine seeking in extinguished rats. I Neurosci 28: 6046-6053.

Peters J, Kalivas PW, Quirk GJ. 2009. Extinction circuits for fear and addiction overlap in prefrontal cortex. Learn Mem 16: 279-288.

Ping A, Xi J, Prasad BM, Wang MH, Kruzich PJ. 2008. Contributions of nucleus accumbens core and shell GluR1 containing AMPA receptors in AMPA- and cocaine-primed reinstatement of cocaine-seeking behavior. Brain Res 1215: 173-182.

Quirk GJ, Likhtik E, Pelletier JG, Pare D. 2003. Stimulation of medial prefrontal cortex decreases the responsiveness of central amygdala output neurons. J Neurosci 23: 8800-8807.

Reissner KJ, Uys JD, Schwacke JH, Comte-Walters S, Rutherford-Bethard JL, Dunn TE, Blumer JB, Schey KL, Kalivas PW. 2011. AKAP signaling in reinstated cocaine seeking revealed by iTRAQ proteomic analysis. J Neurosci 31: 5648-5658.

Reti IM, Baraban JM. 2003. Opiate withdrawal induces Narp in the extended amygdala. Neuropsychopharmacology 28: 1606-1613.

Reti IM, Reddy R, Worley PF, Baraban JM. 2002a. Prominent Narp expression in projection pathways and terminal fields. I Neurochem 82: $935-944$.

Reti IM, Reddy R, Worley PF, Baraban JM. 2002b. Selective expression of Narp, a secreted neuronal pentraxin, in orexin neurons. J Neurochem 82: $1561-1565$.

Reti IM, Han S, Miskimon M, Rosen JB, Baraban JM. 2009. Nicotine and $\Delta^{9}$-tetrahydrocannabinol withdrawal induce Narp in the central nucleus of the amygdala. Synapse 63: 252-255.

Santini E, Quirk GJ, Porter JT. 2008. Fear conditioning and extinction differentially modify the intrinsic excitability of infralimbic neurons. J Neurosci 28: 4028-4036.

Schroeder JP, Packard MG. 2003. Systemic or intra-amygdala injections of glucose facilitate memory consolidation for extinction of drug-induced conditioned reward. Eur J Neurosci 17: 1482-1488.

Shabashov D, Shohami E, Yaka R. 2012. Inactivation of PKM $\zeta$ in the NAc Shell abolished cocaine-conditioned reward. J Mol Neurosci 47: $546-553$.

Sutton MA, Schmidt EF, Choi KH, Schad CA, Whisler K, Simmons D, Karanian DA, Monteggia LM, Neve RL, Self DW. 2003. Extinction-induced upregulation in AMPA receptors reduces cocaine-seeking behaviour. Nature 421: 70-75.

Tsui CC, Copeland NG, Gilbert DJ, Jenkins NA, Barnes C, Worley PF. 1996. Narp, a novel member of the pentraxin family, promotes neurite outgrowth and is dynamically regulated by neuronal activity. J Neurosci 16: $2463-2478$.

Van den Oever MC, Spijker S, Smit AB, De Vries TJ. 2010. Prefrontal cortex plasticity mechanisms in drug seeking and relapse. Neurosci Biobehav Rev 35: $276-284$

Wolf ME, Ferrario CR. 2010. AMPA receptor plasticity in the nucleus accumbens after repeated exposure to cocaine. Neurosci Biobehav Rev 35: $185-211$.

Yao Y, Kelly MT, Sajikumar S, Serrano P, Tian D, Bergold PJ, Frey JU, Sacktor TC. 2008. PKM $\zeta$ maintains late long-term potentiation by $\mathrm{N}$-ethylmaleimide-sensitive factor/GluR2-dependent trafficking of postsynaptic AMPA receptors. J Neurosci 28: 7820-7827.

Received September 15, 2012; accepted in revised form November 27, 2012. 


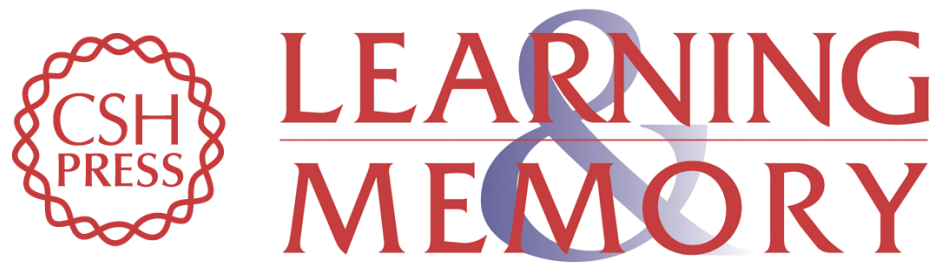

\section{Role of medial prefrontal cortex Narp in the extinction of morphine conditioned place preference}

Ashley M. Blouin, Sungho Han, Anne M. Pearce, et al.

Learn. Mem. 2013, 20:

Access the most recent version at doi:10.1101/Im.028621.112

Supplemental http://learnmem.cshlp.org/content/suppl/2013/01/03/20.2.75.DC1
Material

References This article cites 40 articles, 15 of which can be accessed free at: http://learnmem.cshlp.org/content/20/2/75.full.html\#ref-list-1

License

Email Alerting Receive free email alerts when new articles cite this article - sign up in the box at the Service top right corner of the article or click here. 